\title{
Skin Squamous Cell Carcinoma or Other Skin Carcinomas pN1 TNM Finding v7
}

National Cancer Institute

\section{Source}

National Cancer Institute. Skin Squamous Cell Carcinoma or Other Skin Carcinomas pN1

TNM Finding v7. NCI Thesaurus. Code C88485.

Skin squamous cell carcinoma or other skin carcinomas with metastasis in a single ipsilateral lymph node, $3 \mathrm{~cm}$ or less in greatest dimension. (from AJCC 7th Ed.) 